\title{
THE RIGHT OF USE ANOTHER'S LAND PLOT WITH THE AGRICULTURAL PURPOSES (EMPHYTEUSIS)
}

\section{Goncharenko V. O.}

\section{INTRODUCTION}

Radical changes in the field of land legal relations, which are introduced by including in Art. 14 of the Constitution of Ukraine ${ }^{1}$, property on land, have led to the creation of a system of proprietary rights on land, among which one of the closest in content to property on land is the right of use another's land plot for agricultural purposes (emphyteusis).

In the civil legislation of Ukraine, the relations about emphyteusis are regulated by the norms of property and contract law. The peculiarity of the legal regulation of emphyteusis under the civil law of Ukraine is the absence of its legal definition, while its essence is contained in the rules that usually regulate the rights and responsibilities of the parts of such legal relations, which necessitates the analysis of the features of this proprietary right to another's property.

Until 2004, the norms of civil law were not applied to the regulation of land relations, except for those property relations that have arose and organically combined with public relations in the field of use and protection of land, natural resources, environmental protection (damages, transfer of ownership of buildings and structures on land plots, inheritance of land plots, civil liability for violation of land law, natural resources and environmental legislation etc.). This is due to the fact that in Art. 2 of the Civil Code of the $\mathrm{USSR}^{2}$ of 1963 the principle of separate legal regulation of property relations by the rules of civil law was provided, while land, forest, water, mining relations - respectively, by the rules of land, forest, water and subsoil legislation.

The reform of this model of legal regulation of land relations took place with the entry into force of the Civil Code of Ukraine $^{3}$ of 2003, which re-established provisions for the application of civil law to regulate public relations in use of land, natural resources and protection of environment.

1 Конституція України: Закон України від 28.06.1996 р. № 254к/96-ВР. Відомості Верховної Ради Украӥни. 1996. № 30. Ст. 141.

${ }^{2}$ Цивільний кодекс Української РСР: Закон Української РСР від 18 липня 1963 р. Відомості Верховної Ради Украӥнської РСР. 1966. № 46.

${ }^{3}$ Цивільний кодекс України: Закон України від 16.01.2003 р. Офіційний вісник Украӥни. 2003. № 11. Ст. 461. С. 7. 
According to Art. 1 of the Civil Code of Ukraine, this act applies to the regulation of land, natural resources, ecological relations within the limits set up by the Civil Code of Ukraine. Therefore, in paragraph 1. Art. 9 of the Civil Code of Ukraine it is provided that the provisions of the Civil Code of Ukraine apply to the settlement of relations arising in the areas of use of natural resources and environmental protection, if they are not regulated by other legislation.

In the Land Code of Ukraine ${ }^{4}$ provisions on the correlation of its norms with the norms of other branches of law have been included. Thus, Part 1 of Art. 3 of the Land Code of Ukraine provides that "the land relations are regulated by the Constitution of Ukraine, this Code, as well as normative legal acts adopted in accordance with them".

Since the Civil Code of Ukraine was adopted two years after the adoption of the Land Code of Ukraine, problems of theoretical and practical nature regarding the relationship between civil and land legislation arose. Different approaches to legal regulation in the Civil Code of Ukraine and the Land Code of Ukraine of the right of use another's land plot for agricultural purposes (emphyteusis) indicate a problem with distinguishing between civil law and land law regulation of this right.

In the context of European integration processes, in order to provide legal conditions for the development of the institution of emphyteusis, it is necessary to develop proposals for amendments to the current civil and land legislation of Ukraine.

\section{The main features of emphyteusis under the civil legislation of Ukraine}

The civil legislation of Ukraine determines the main features and grounds for emphyteusis. However, it should be noted that the Civil Code of Ukraine does not define emphyteusis, and its essence can be clarified only from the analysis of its characteristic features under Art. 407 of the Civil Code of Ukraine. In particular, in accordance with Part 1 of Art. 407 of the Civil Code of Ukraine, the right of use another's land plot for agricultural purposes is established by a contract between the owner of the land and a person who has expressed a desire to use this land for agricultural purposes (hereinafter - the land user). This indicates that the only basis for the occurrence of such a proprietary right as emphyteusis is a contract between the owner of the land and the land user (emphyteuta).

4 Земельний кодекс України: Закон України від 25.10.2001р. № 2768-III. Відомості Верховної Ради України. 2002. № 3. Ст. 27. 
According to Part 2 of Art. 407 of the Civil Code of Ukraine emphyteusis may be subject to alienation on the basis of the contract and can be inherited. That is, emphyteusis can be sold, donated, exchanged and otherwise transferred to another person. However, it should be borne in mind that only the proprietary right to use the land plot can be alienated, and not the land plot itself in respect of which emphyteusis has been established.

At the same time, Part 3 of Art. 407 of the Civil Code of Ukraine and Part 3 of Art. 102-1 of the Land Code of Ukraine stipulate that the right of use a land plot of state or communal property for agricultural purposes may not be alienated by its land user to other persons, included in the statutory fund, pledged. It seems that this legal norm unjustifiably narrows the range of powers of the land user in the case of establishing of emphyteusis in relation to state or communal lands.

After all, the right to use a land plot on the basis of emphyteusis is not related to the restrictions established by law (we meen the ban until July 1, 2021 on the right to make contributions by land shares to the share capital of the companies and to sell agricultural land, provided by paragraphs 14 and 15 of Section X of the Land Code of Ukraine) in relation to land plots for agricultural purposes, as emphyteusis provides only the right to use someone else's land plot and does not cover the right to dispose of it.

By introducing a restriction on the selling of emphyteusis established for land plots of state or communal property for agricultural purposes, the legislator is trying to limit the privatization of the land fund of Ukraine. However, the position of the legislator is incorrect, because the alienation of the emphyteutic right does not affect the change of owner of the land in respect of which the emphyteusis is established.

Similarly, we have to underline the injustice of the exemption established by the Civil Code of Ukraine regarding the terms of the contract of emphyteusis for land plots of state or communal property. So, Part 1 of Art. 408 of the Civil Code of Ukraine sets a maximum term of 50 years for the contract of emphyteusis established for land plots of state or communal property.

Moreover, it is not clear how to apply the provisions of Part 4 of Art. 102-1 of the Land Code of Ukraine, according to which the term of use of land of state, communal and private property for agricultural purposes (emphyteusis) may not exceed 50 years.

First of all, it should be noted that this norm shows the tendency of the legislator to identify the property right of emphyteusis with the obligatory right to lease the land, for which in Part 4 of Art. 93 of the Land Code of Ukraine it is also provided a maximum term of 50 years.

In addition, the lack of understanding by the legislator of the essence of the division of rights into property and obligations is evidenced by the inclusion in land legislation provisions about the possibility of alienating the 
right of land lease, including by sale at land auction, as well as pledge, inheritance, deposit to the share capital of the company - for a period of up to 50 years, except in cases specified by law.

Thus, before the introduction of the specified innovation to Part. 5 of Art. 93 of the Land Code of Ukraine, the need to include the emphyteusis in the civil legislation of Ukraine was explained by the fact that the rights of the tenant of land can not be considered as a proprietary right, because they can not be the subject of an independent contract of sale (although they can, in some cases, be inherited) ${ }^{5}$.

It is important to note that in the case of sale of the right to lease the land the preemptive right to purchase this right by the owner of the land is not provided for, as provided in the case of sale of emphyteusis in accordance with Part 2 of Art. 411 of the Civil Code of Ukraine. In addition, setting a maximum term for a emphyteusis agreement is not compatible with the main feature of this institution as a lifelong right, the purpose of which is such a fiduciary attitude to the land as to its own, which is directly ensured by the indefinite use of the object of emphyteusis. Sukhanov ${ }^{6}$ noted that emphyteusis is essentially a perpetual lease. Therefore, the provision on the establishment of a maximum term of 50 years for the emphyteusis agreement established in respect of land of state or communal ownership, should be excluded from Part 1 of Art. 408 of the Civil Code of Ukraine.

So, the legislative regulation of the maximum terms of the emphyteusis contract is not appropriate. It is more probable that it is necessary to establish the minimum terms of emphyteusis. In determining the minimum terms of the contract of emphyteusis should by analogy use of the provisions of Part 3 of Art. 19 of the Law "On Land Lease", , according to which the lease of agricultural land for commercial agricultural production, farming the term of the lease contract is determined by agreement of the parties, but may not be less than 7 years.

The most important feature of emphyteusis is its proprietary nature with the simultaneous emergence of this institution on the basis of the contract. An important consequence of the recognition of the proprietary nature of emphyteusis is the absolute nature of the protection of rights of land user. According to Art. 396 of the Civil Code of Ukraine, the provisions on the

5 Покровский И.А. Основные проблемы гражданского права. М.: Статут (в серии “Классика российской цивилистики”). 1998. 353 с. С. 36.

6 Суханов Е.А. Проблемы правового регулирования отношений публичной собственности и новый Гражданский кодекс. Гражданский кодекс. Проблемы. Теория. Практика: Сборник памяти С.А. Хохлова. М., 1998. 480 с. С. 299.

${ }^{7}$ Про оренду землі: Закон України від 06.10.1998 р. № 161-XIV. Відомості Верховної Ради України. 1998. № 46-47. Ст. 280. 
protection of property rights (Chapter 29 of the Civil Code of Ukraine) also apply to emphyteusis as a proprietary right to another's property. At the same time, protection (by vindication and negator lawsuits) is provided not only from violations by third parties, but also from the actions of the owner of the land plot in respect of which emphyteusis has been established.

According to the classical definition of absoluteness, property rights are protected from any person, regardless of the change of owner of the thing. It is the proprietary nature of emphyteusis that explains the preservation of this right in the case of transfer of property on land plot to other persons. So, there is a principle known to classical Roman private law, according to which property right follows the things in respect of which it is established, and not directly related to the holders of these rights.

The characteristic of "following" is an element of the absoluteness of property rights. In turn, "following" affects the content of another characteristic of property rights - the principle of individualization (specialty, certainty) of property right, according to which property right arises in relation to an individually-defined thing, ends with its death and follows it everywhere, regardless of change the owner of the thing. All of the above is characteristic of emphyteusis, and therefore: emphyteusis does not end with the change of owner of the land plot and its object is an individually-defined thing - agricultural land. Also, by virtue of the principle of specialty, a separate contract must be concluded for each land plot, which provides for the emergence of emphyteusis, as proprietary right cannot arise in relation to a set of things.

The alienation of emphyteusis means that it can be transferred by the land user to another person under any civil contract, except as provided in Part 3 of Art. 407 of the Civil Code of Ukraine. This contract can be both payment or free. In accordance with Part 2 of Art. 411 of the Civil Code of Ukraine in case of sale of the right to use the land the owner of this land has a priority over other persons to purchase it at the price, announced for sale, and on other equal conditions. The right of priority is not used in the case of the sale of emphyteusis at public auction, when the emphyteuta is a bankrupt or sanctions for the offense are applied, because in this case there is a forced sale. The priority right applies only to the paid alienation of emphyteusis, and therefore cannot be applied in the case of alienation by donation.

In the procedure of sale of emphyteusis, the seller of it is obliged to notify in writing the owner of the land plot provided for use about the intention to sell his right of use to a third party indicating the price announced for sale and other conditions of sale.

The owner of the land plot, who within one month declares in writing his intention to buy the emphyteusis, is obliged to buy it at the price and on the 
conditions announced for sale. If the landowner refuses to purchase the emphyteusis or does not give written consent to the purchase, or agrees to a possible purchase at another price, the land user has the right to sell his right to any person, but on terms previously announced for sale. If the owner of the land plot, having agreed to the purchase of emphyteusis, subsequently abandons his intention, the land user may demand from him compensation for damage caused by such refusal, in accordance with Art. 22, 23 of the Civil Code of Ukraine.

If a land user sells an emphyteusis in violation of the owner's right to preferential purchase, the landowner may apply to the court within one year to transfer the rights and obligations of the buyer. The right of preferential purchase will be considered violated in the case of: a) failure to notify the owner of the land plot of future sale, including noncompliance with the form of notification or failure to indicate in the notice of all terms of sale; b) sale of the emphyteutical right earlier before the time; c) providing the landowner with information about the terms of the future sale, which do not correspond to reality; d) changes in the terms of sale compared to those previously announced; e) the conclusion of a fictitious transaction aimed at violating the right of preferential purchase of emphyteusis, and others violations aimed at restricting or depriving the owner of the land plot of the preferential purchase. At the same time, the plaintiff is obliged to deposit into the deposit account of the court the amount of money that the buyer must pay under the contract (Part 4 of Art. 411, Art. 362 of the Civil Code of Ukraine).

Since the right to use a land plot of state or communal property cannot be alienated by its land user to other persons (Part 3 of Art. 407 of the Civil Code of Ukraine), the content of Art. 127 of the Land Code of Ukraine, in which as an alienator of emphyteusis defined public authorities, the Council of Ministers of the Autonomous Republic of Crimea and local governments in accordance with their powers under Art. 122 of the Land Code of Ukraine. It is also noted that the purchasers of emphyteusis can be citizens, legal entities and foreign states on the grounds and in the manner prescribed by the Land Code of Ukraine. Thus, in Art. 127 of the Land Code of Ukraine implies, despite its name, the paid establishment of emphyteusis, rather than the sale of existing emphyteutic right.

The sale of the right of emphyteusis on land plots of state and communal property on a competitive basis in the form of an auction is carried out in the cases and in the manner prescribed by Chapter 21 of the Land Code of Ukraine (Part 2 of Art. 127 of the Land Code of Ukraine).

In accordance with Part 1 of Art. 133 of the Land Code of Ukraine, emphyteusis may be pledged, unless otherwise provided by law. 
In accordance with Part 3 of Art. 407 of the Civil Code of Ukraine the right of use of the land plot of the state or municipal property for agricultural needs isn't transferred in the pledge. The transfer of the right to a part of the land plot as a pledge is carried out after its allocation on the ground in accordance with the land management documentation. Pledgee of agricultural land plot and property rights on it (lease, emphyteusis) can only be banks (Part 3, 4 of Art. 133 of the Land Code of Ukraine).

Also the characteristic of emphyteusis is that it can be inherited both on the basis of a will and by the law. A feature of emphyteusis, which, in particular, helps to distinguish it from superficies, is its purpose. The land is given to the user of superficies only for construction, and to the emphyteuta only for agricultural purposes.

The Civil Code of Ukraine provides for only one basis for the emergence of emphyteutic law - the contract between the owner of the land and a person who has expressed a desire to use this land for agricultural purposes. However, emphyteusical law may arise on other grounds, in particular, by will. For example, it is not clear why the legislator allows the establishment of superficies by will, but does not provide such a basis for the emergence of emphyteutic law. Established by law (Part 2 of Art. 411 of the Civil Code of Ukraine), the right of priority for the landowner to buy an emphyteutic right is provided only for the sale of an existing emphyteutical right, and therefore cannot be an obstacle to the existence of a will as a basis for emphyteusis. Therefore, it is necessary to supplement Part 1 of Art. 407 of the Civil Code of Ukraine and Part 1 of Art. 102-1 of the Land Code of Ukraine by amendment that emphyteusis can also be established by will.

Thus, the most important feature of emphyteusis is its proprietary nature with the simultaneous emergence of this institution on the basis of the contract. Thus, emphyteusis harmoniously combines the binding legal basis of origin and all the features characteristic of property law, such as: absoluteness, special object - agricultural land, long-term, alienability, heredity, purpose, "following" the thing. In addition, the characteristics of emphyteusis as a proprietary right to another's property are: limited in comparison with the property content (usually excludes the right to dispose of the object of property rights, and in case of emphyteusis the law prohibits the sale of state or communal land for agricultural use needs, as well as the prohibition provided for the deposit of emphyteutic rights to the share capital, its transfer as pledge- Part 3 of Art. 407 of the Civil Code of Ukraine), secondary to property rights, the principle of limiting property rights and restoring it in full in case of cancellation of limited property rights (the principle of elasticity of property rights). 


\section{The contract of emphyteusis}

Under the contract of emphyteusis one party (the owner of the land plot) transfers the agricultural land plot for use to the other party (land user, emphyteuta), and the land user is obliged to use it in accordance with the purpose and terms of the contract.

In the structure of the relationship about the emphyteusis, it is necessary to distinguish the grounds for the occurrence of emphyteusis from the grounds for the acquisition of an existing emphyteusis right by a new subject. Emphyteusis can be transferred under a contract between the previous and next land user, and by inheritance. The emphyteutist may alienate his right as for charge and free of charge, in particular, the emphyteutic right may be the subject of a contract of sale, donation, exchange, pledge and may be transferred in any manner not prohibited by law to another individual or legal entity, except for the right to use land of state or communal property for agricultural purposes. The alienation of emphyteusis is not about the transfer of ownership of the land, but about the alienation of the right to use it exclusively.

The characteristics of the contract of emphyteusis, first of all, require the definition of the features of this contract. Thus, the use of land on the terms of emphyteusis is limited and targeted, because in case of emphyteusis, the owner transfers to the user the posession and the right of targeted use, while retaining the right to dispose of land. The legal purpose of the land plot provided for use is determined by the contract of emphyteusis. Therefore, the parties may not specify in the contract of emphyteusis any other legal purpose of the land plot than use for agricultural purposes.

In accordance with Part 5 of Art. 626 of the Civil Code of Ukraine, the contract is a payment agreement, unless otherwise provided by contract, law or does not follow from the essence of the contract. So the contract of emphyteusis is a payment agreement, if its gratuitousness is not expressly provided by the contract.

In parts 1 and 2 of Art. 640 of the Civil Code of Ukraine the presumption of consensual character of it is established. The enshrinement of this presumption in law is explained by the fact that the agreement is a mandatory term for the conclusion of the contract, and the transfer of the thing only complements it and it is necessary only for certain types of contracts. The contract of emphyteusis is consensual, as the transfer of land is not required for the emergence of emphyteusis. At the same time, it is impossible to exercise this right before the boundaries of the plot are established on the ground, as it is prohibited by law to start using the land plot (Art. 125 of the Land Code of Ukraine). In addition, emphyteusic right arises from the moment of its state registration. Thus, the moment of concluding of a contract of emphyteusis and the transfer of property rights do not coincide in time (Art. 334 of the Civil Code of Ukraine). 
In addition, the contract of emphyteusis can be described as bilateral and reciprocal, as the obligation of the landowner to transfer it for use corresponds to the emphyteusis' right to demand such transfer.

The form of the contract of emphyteusis is not stipulated separately in the civil legislation of Ukraine. Land Code of Ukraine in Part 6 of Art. 102-1 also contains a very clear provision that the conclusion of the contract of emphyteusis is carried out in accordance with the Civil Code of Ukraine, taking into account the requirements of the Land Code of Ukraine. Thus, notarization of the contract of emphyteusis may be carried out by agreement of the parties.

However, the third paragraph of Part 6 of Art. 102-1 of the Land Code of Ukraine provides for special requirements regarding to the form of the emphyteusis agreement. Thus, the owner of the land plot may establish a requirement for notarization of the contract of emphyteusis and cancel such a requirement. Establishment (cancellation) of the claim is a unilateral transaction subject to notarization. Such a requirement is an encumbrance of property rights on land and is subject to state registration in the order prescribed by law.

It is important to note that the proprietary right to use the land for agricultural purposes (emphyteusis) is subject to state registration in accordance with Art. 182 of the Civil Code of Ukraine and in the order prescribed by the Law of Ukraine "On state registration of proprietary rights to immovable property and their encumbrances" $"$, and therefore the contract of emphyteusis is not subject to state registration.

Thus, the emphyteutic right arises from the moment of state registration of this right, and the contract between the owner of the land plot and the person who has expressed desire to use this land plot for agricultural needs, is concluded from the moment of its signing or notarization.

In contrast to the land lease agreement, the essential terms of the contract of emphyteusis are not defined by law. In accordance with Part 1 of Art. 638 of the Civil Code of Ukraine, a contract is concluded if its parties have duly agreed on all the essential terms of the contract. The essential terms of the contract are the conditions on the subject of the contract, the conditions defined by law as essential or necessary for contracts of this type, as well as all those conditions on which at the request of at least one of the parties must be agreed ${ }^{9}$.

\footnotetext{
${ }^{8}$ Про державну реєстрацію речових прав на нерухоме майно та їх обтяжень: Закон України від 01.07.2004 р. № 1952-IV. Відомості Верховної Ради Украӥни. 2004. № 51. Ст. 553.

${ }^{9}$ Брагинский М.И. Договорное право. Общие положения. М.: Изд-во “Статут”, 1998. C. $295-339$.
} 
An essential condition of any contract without exception, and hence the contract of emphyteusis, is the condition of its subject. The subject of the contract of emphyteusis is a land plot provided for use for agricultural purposes. Agricultural land that is transferred to emphyteusis may be in private, communal or state property.

The parties to the contract of emphyteusis may narrow the boundaries of the land use (for example, by stating that it should be used for arable land or perennial plantings, etc.), but not expand them, as agricultural land is used by their owners or users only within the requirements for use of lands of a certain type established by Art. 31, 33-37 of the Land Code of Ukraine (paragraph 2 part 5 of Art. 20 of the Land Code of Ukraine).

Currently, the issue of establishing of requirements for the quality of land transferred for use on the basis of the contract of emphyteusis is unresolved. The only requirement for the land plot is the purpose, i.e. belonging of the land plot to the category of agricultural land. However, the composition of lands of this category, in addition to productive, includes lands that are not used in agricultural production (e.g., swamps, ravines etc. $)^{10}$. In order to guarantee the rights of land user, we propose to establish the mandatory fertility characteristics of the land plot that is transferred to emphyteusis.

The validity period of the contract of emphyteusis is set by the agreement of its parties. If the right of emphyteusis is established for an indefinite period, each of the parties may withdraw from the contract, notifying the other party at least 1 year before such refusal (Part 2 of Art. 408 of the Civil Code of Ukraine).

At the same time, the owner of the private land plot and the emphyteuta can no longer enter into such an agreement for a period of more than 50 years due to the provisions of Part 4 of Art. 102-1 of the Land Code of Ukraine. In this case, there is a tendency of the legislator to identify the categories of land lease and emphyteusis, which leads to the exclusion from economic relations of such an important institution as emphyteusis.

The fee in the contract of emphyteusis is a payment made by the land user to the landowner. According to Art. 632 of the Civil Code of Ukraine, the price in the contract is set by agreement of the parties. In cases specified by law, prices (tariffs, rates etc.) are applied, which are set or regulated by authorized state authorities or local governments. The fee in the rent for land plots of state and communal property is a regulated price, and therefore the legislative change of the maximum amount of this fee is the basis for revision of the amount of rent established by the terms of the contract. However, in a

${ }^{10}$ Глотова О.В. Правове регулювання правочинів щодо земельних ділянок в Україні: автореф. дис. ... канд. юрид. наук: 12.00.06. К., 2003. 20 с. 
relationship of emphyteusis, the price cannot be regulated, even in the case of establishing emphyteusis in relation to a land plot of state or communal property. Therefore, we do not consider it expedient to propose legislative regulation of the minimum or maximum amount of payment for emphyteusis. The exclusively private-law nature of the regulation of emphyteusis differs favorably from the currently over-regulated land lease obligations.

The calculation of the amount of the fee in the contract of emphyteusis should be carried out taking into account inflation indices, unless otherwise provided by the contract. The amount of the fee for emphyteusis can vary significantly depending on the nature of land use and the conditions of its provision $^{11}$.

In contrast to the land lease agreement, for which the law in Part 2 of Art. 21 of the Law of Ukraine "On Land Lease" puts forward special requirements for the payment of rent for land plots of state and communal property, for the contract of emphyteusis law provides full freedom in determining the amount, form and terms of payment under this agreement. Thus, the fee for emphyteutic land use is paid to the owner of the land in the amount, form, order, conditions and within the period specified in the contract.

The fee in the contract of emphyteusis may be changed with the consent of the parties to this contract. The emphyteuta should have the right to demand a corresponding reduction in the fee under the contract if the condition of the land plot transferred to the emphyteusis has deteriorated without his fault. In this regard, it is advisable to add this right to change the amount of payment under the contract at the request of the emphyteuta in the civil legislation of Ukraine.

However, the fee for the use of land of state or communal property, defined in the the contract of emphyteusis, concluded at the land auction, may not be reduced by agreement of the parties during the contract and also in case of its renewal (Part 5 of Art. 102-1 of the Land Code of Ukraine).

At the same time, the contract of emphyteusis may be free of charge. In this case, the question arises: does the possibility of free transfer of land in the emphyteusis fit to all forms of land property? It is thought that gratuitous transfer of land for use on the basis of the contract of emphyteusis can take place only in the case of concluding an agreement on a land plot of private land fund, as transfer of land for use from state and communal funds without payment is contrary to fiscal interests of a state.

11 Емелькина И.А. Система ограниченных вещных прав на земельный участок: монография. М.: Волтерс Клувер, 2011. С. 39. 
The analysis of the civil and land legislation of Ukraine about the right of use another's land plot for agricultural purposes allowed to determine the conditions of the contract of emphyteusis:

1) the subject of the contract of emphyteusis (cadastral number, location and size of the land plot);

2) payment for land use with indication of its size, indexation, forms of payment, terms, the order of its introduction and revision and responsibility for its non-payment;

3) conditions of use and legal purpose of the land plot ;

4) conditions for preserving the state of the object of emphyteusis;

5) conditions and terms of transfer of the land plot to the land user;

6) conditions for returning the land plot to its owner;

7) existing restrictions of use of land plot and encumbrances of proprietary rights on land;

8) identification of the party that carries the risk of accidental damage or destruction of the land plot or a part of it;

9) responsibility of the parties.

With the consent of the parties, the contract of emphyteusis may specify other conditions, including the quality of land, the procedure for fulfilling the obligations of the parties, the procedure for insuring the land, the procedure for reimbursement of costs for protection and improvement of the object of emphyteusis, reclamation works, as well as circumstances that may affect the change or termination of , the contract of emphyteusis etc.

The content of the contract is the rights and obligations of its parties. Under the contract of emphyteusis, the landowner is obliged to transfer the land plot to the land user. The transfer of the object of the contract of emphyteusis to the land user must be carried out by the owner of the land within the terms and conditions specified in the contract of emphyteusis on the basis of the act of acceptance-transfer. The owner of the land plot is obliged not to prevent the land user from exercising his rights (Part 3 of Art. 409 of the Civil Code of Ukraine). In accordance with Part 1 of Art. 409 of the Civil Code of Ukraine, the owner of the land has the right to require the land user to use it for the purpose specified in the contract. The owner of the land plot is also entitled to receive a fee. The amount of payment, its form, conditions, procedure and terms of its payment are established by the contract (part 2 of Art. 409 of the Civil Code of Ukraine). The owner of the land has in accordance with Part 2 of Art. 411 of the Civil Code of Ukraine, the preemptive right of acquisition, as well as to receive interest on the sale price of emphyteusis to another person - the so-called "laudemia" (Part 5 of Art. 411 of the Civil Code).

The land user has the responsibilities provided for in the norms of Part 2 and 3 of Art. 410 of the Civil Code of Ukraine, Art. 96 of the Land Code of 
Ukraine. Thus, the land user is obliged to: 1) ensure the use of land for its intended purpose, increase its fertility, apply environmental production technologies, comply with environmental legislation, refrain from actions that could lead to environmental degradation and at its own expense to bring it to the previous state in case of illegal change of its relief, except for cases of illegal change of relief by another person (part 3 of Art. 410 of the Civil Code of Ukraine, Art. 96 of the Land Code of Ukraine); 2) to pay in time the fee under the contract of emphyteusis, as well as other payments established by law (Part 2 of Art. 410 of the Civil Code of Ukraine, Art. 96 of the Land Code of Ukraine); 3) not to violate the rights of owners of adjacent land plots and land users (of Art. 96 of the Land Code of Ukraine); 4) increase soil fertility, apply environmental production technologies, refrain from actions that may lead to deterioration of the ecological situation and preserve other useful properties of the land (Art. 96 of the Land Code of Ukraine); 5) timely provide the relevant executive authorities and local governments with data on the condition and use of land and other natural resources in the manner prescribed by law (Art. 96 of the Land Code of Ukraine); 6) comply with the rules of good neighborliness and restrictions associated with the establishment of land easements and protection zones (Art. 96 of the Land Code of Ukraine); 7) to store geodetic signs, anti-erosion constructions, networks of irrigation and drainage systems (Art. 96 of the Land Code of Ukraine); 8) notify the owner of the land of the intention to sell the right (Art. 96 of the Land Code of Ukraine).

The land user has the right to: effectively use the land in full in accordance with the contract (Part 1 of Art. 410 of the Civil Code of Ukraine) and independently manage the land (p.a) Part 1 of Art. 95 of the Land Code of Ukraine); to acquire ownership of crops and plants, for manufactured products (p.b) Part 1 of Art. 95 of the Land Code of Ukraine); use in the prescribed manner for their own needs available on the land common minerals, peat, forests, water, as well as other useful properties of the land (p. c) Part 1 of Art. 95 of the Land Code of Ukraine); claim for damages in cases provided by law (p. g) Part 1 of Art. 95 of the Land Code of Ukraine); to transfer the right to use land for agricultural purposes by inheritance; to alienate the right to use the land plot for agricultural needs, unless otherwise provided by law (Art. 411 of the Civil Code of Ukraine).

\section{CONCLUSIONS}

The analysis of the norms of the Civil Code of Ukraine and the Land Code of Ukraine regulating the right of use another's land plot for agricultural purposes (emphyteusis) allows us to draw the following conclusions. Thus, these Codes lack unity in the legal model of regulating of public relations about the land. The norms of the Civil Code of Ukraine and the Land Code of 
Ukraine contain unnecessary repetitions of normative material. It is undeniable that the institution of property rights, including land rights, is an institution of civil law. Of course, any codified act and, in particular, the Land Code of Ukraine, is not devoid of elements of complexity. However, the inclusion in the Land Code of Ukraine of norms of civil law (private law) by its nature means not only unnecessary duplication of law, but also a mixture of subjects and principles of regulation of private and public law. Such mixing leads only to contradictions and artificial complication of legal regulation, and in practice to the weakening of state control over the use of land. Therefore, the provisions of Chapter 16-1 of the Land Code of Ukraine on emphyteusis and superficies should contain only a reference to the relevant articles of the Civil Code of Ukraine.

The specific features of emphyteusis as a proprietary right include the fact that it may be sold and inherited. However, only the proprietary right to use the land plot can be alienated, and not the land plot itself in respect of which emphyteusis has been established.

An important consequence of recognizing the proprietary nature of emphyteusis is to give the land user the absolute nature of protection of his rights. According to Art. 396 of the Civil Code of Ukraine, the provisions on the protection of property rights (Chapter 29 of the Civil Code of Ukraine) also apply to emphyteusis as a proprietary right to another's property.

\section{SUMMARY}

The paper is devoted to a characteristic of emphyteusis in civil legislation of Ukraine. The origin, essence, terms and peculiarities of emphytheusis according to the civil legislation of Ukraine have been analyzed and its concept and ways of improvement of emphytheusis have been determined in the thesis. Definition of the contract of emphyteusis is given based on analysis of science literature, national legislation and drafts of normative and legal acts of Ukraine.

The main characteristic of the contract of emphytheusis is given in the paper. The conditions of the contract of emphyteusis according to the civil legislation of Ukraine have been analyzed.

The specific features of emphyteusis as a proprietary right include the fact that it may be subject to alienation on the basis of a contract and transferred by inheritance. The proprietary right to use the land plot can be alienated, but not the land plot itself.

An important consequence of the recognition of the proprietary nature of emphyteusis is to give the land user (emphyteuta) the absolute power of the protection of his rights. According to Art. 396 of the Civil Code of Ukraine, the provisions on the protection of property rights (Chapter 29 of the Civil Code of Ukraine) also apply to emphyteusis as a proprietary right to another's property. 
Several conclusions in the emphytheusis theory was accomplished. On this basis, propositions as to the improvement of current civil legislation concerning legal regulation of emphytheusis were formulated.

\section{REFERENCES}

1. Брагинский М.И. Договорное право. Общие положения. М.: Изд-во “Статут”, 1998. 682 с.

2. Глотова О.В. Правове регулювання правочинів щодо земельних ділянок в Україні: автореф. дис. ... канд. юрид. наук: 12.00.06. Київ, 2003. $20 \mathrm{c}$.

3. Емелькина И.А. Система ограниченных вещных прав на земельный участок: монография. М.: Волтерс Клувер, 2011. 368 с.

4. Земельний кодекс України: Закон України від 25.10.2001p. № 2768-III. Відомості Верховної Ради України. 2002. № 3. Ст. 27.

5. Конституція України: Закон України від 28.06.1996 р. № 254к/96ВР. Відомості Верховної Ради України. 1996. № 30. Ст. 141.

6. Покровский И.А. Основные проблемы гражданского права. Москва : Статут (в серии “Классика российской цивилистики”). 1998. 353 c. C. 36.

7. Про оренду землі: Закон України від 06.10.1998 p. № 161-XIV. Відомості Верховної Ради Украӥни. 1998. № 46-47. Ст. 280.

8. Про державну реєстрацію речових прав на нерухоме майно та їх обтяжень: Закон України від 01.07.2004 p. № 1952-IV. Вiдомості Верховної Ради Украӥни. 2004. № 51. Ст. 553.

9. Суханов Е.А. Проблемы правового регулирования отношений публичной собственности и новый Гражданский кодекс. Гражданский кодекс. Проблемьл. Теория. Практика: Сборник памяти С.А. Хохлова. Москва, 1998. 480 с.

10. Цивільний кодекс Української РСР: Закон Української РСР від 18 липня 1963 р. Відомості Верховної Ради Украӥнської РСР. 1966. № 46.

11. Цивільний кодекс України: Закон України від 16.01.2003 p. Офіиійний вісник Украӥни. 2003. № 11. Ст. 461.

\section{Information about the author:} Goncharenko V. O., $\mathrm{PhD}$, Associate Professor, Associate Professor of Civil Law Department National University "Odesa Law Academy" Academichna, 9, Odesa, Ukraine ORCID ID: https://orcid.org/0000-0001-9114-0276 